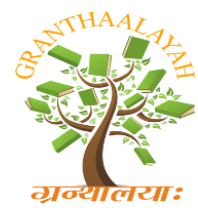

INTERNATIONAL JOURNAL OF RESEARCH GRANTHAALAYAH A knowledge Repository

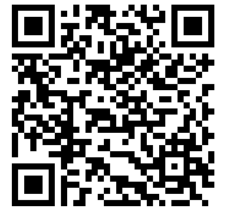

Social

\title{
BURDEN, SEASONALITY, SEX RATIO AND PREFERRED SITES OF TICKS OF PUBLIC HEALTH IMPORTANCE ON CATTLE FOUND AT AMANSEA, ANAMBRA STATE NIGERIA
}

\author{
Ikpeze, O.O. ${ }^{* 1}$, Eneanya, C.I. ${ }^{2}$, Onyido, A.E. ${ }^{3}$ \\ *1, 2, 3 Department of Parasitology and Entomology, Nnamdi Azikiwe University, PMB 5025
} Awka, Anambra State, NIGERIA

\begin{abstract}
Cattle from arid north which graze at Amansea in southern Nigeria were thought to introduceticks in the new area. Burden, seasonality, sex ratio and preferred sites of ticks on cattle were studied in late wet season of 2012 and early dry season of 2013 at Amansea. Cattle $(n=200)$ were randomly selected and examined both visually and manualy for tick infestation. Genera Amblyomma, Boophilus, Hyalomma and Rhipicephalus species constituted 69.6; 11.9; 13.8 and 7 percentagesof all ticks encountered, at 2.87 ticks per infested cattle. Wet and dry seasons accounted for $68 \%$ and $32 \%$ of the ticks, generally in ratio of $1.9 \% 1$. Preferred sites were in descending order of magnitude; scrotum \udder, tail, back, fore leg, neck, ear, dewlap, groin, head (face), brisket, belly, shoulder, side, hind leg and escutcheon $(\chi 2=175.8472$, df $=42, P<0.01$ ). Potential tick-bites areas which abound in Amansea are risk factors fortickborne diseases (TBD) known to be transmitted by ticks in West Africa. Results from this study will create public awareness on TBD and may be useful in evidence-based policy decisions on restriction of cattle movement, tick control and surveillance of TBD in the area.
\end{abstract}

Keywords:

Cattle, ticks, tick-bites, tick-borne disease, tick control, TBD surveillance.

Cite This Article: Ikpeze, O.O., Eneanya, C.I., and Onyido, A.E., "BURDEN, SEASONALITY, SEX RATIO AND PREFERRED SITES OF TICKS OF PUBLIC HEALTH IMPORTANCE ON CATTLE FOUND AT AMANSEA, ANAMBRA STATE NIGERIA" International Journal of Research - Granthaalayah, Vol. 3, No. 12(2015): 61-71.

\section{INTRODUCTION}

Ticks are cosmopolitan but are more prevalent in warmer climates [1] especially in tropical and sub-tropical areas where they are ectoparasites responsible for severe economic losses and impact on the productivity of indigenous cattle under ranch conditions [2] due to their ability to transmit protozoan, Rickettsial and viral diseases [3]. Tick-bites in humans could also result in tick-borne infectious diseases, e.g., human babesiosis [4] and severe toxic conditions such as 
paralysis and toxicosis, irritation and allergy [5] caused by a neurotoxin synthesized, for example. in the salivary gland of female Rhipicephalus evertsi evertsi [6].

Dry environmental conditions are dangerous for ticks, particularly to the questing larvae which are very susceptible to drying out fatally but the survival of many species is improved if they have a seasonal cycle which reduces these risks. Most of the ticks occurred in relatively low number throughout the year, but were generally most common from the second half of the rainy season through the dry seasonin Nigeria [7] especially July and September [8]. In Nigeria, the nomadic system of grazing exposes cattle to ticks infestation [9] by at least four genera of ticks, Amblyomma, Boophilus, Hyalomma, and Rhipicephalus species [3] which transmit pathogens that cause important tick-borne diseases (TBD) of cattle [9] which may also be transmitted to humans through infective tick-bites. It has been observed that unrestricted movement of livestock in search of water and pasture increases and promotes tick-host contact and could result to high prevalence of tick infestation among cattle [10].

Moreover, potential outbreaks of tick-borne blood protozoan diseases may occur if infected cattle are moved from one tick-prevalent region to another. It was reported [11] that unrestricted livestock movement from area to area in search of water and grazing lands which is a common phenomenon increases and promotes tick-host contact; thus contributing to tick distribution and introduction of tick borne diseases. Cattle that continuously graze from northern Nigeria to the south usuallyintroduce ticks in the southern environment, which is very suitable for the development and maintenance of ticks [12,13,14]. The present study focused on burden, seasonality, sex ratio and preferred sites of ticks found on cattle at Amansea, south-eastern Nigeria with the aim that data generated from will be used to create awareness on health hazards associated with unrestricted cattle movement and ticks in an environment. Policy makers may find the result useful in evidence-based decision to control ticks or initiate surveillance on TBD in the area.

\section{MATERIAL AND METHODS}

Study area: The study was conducted at Amansea (Latitude 60 14' 19.97"N; Longitude 70 06' $56.92 " \mathrm{E})$ in rainforest and derived guinea savannah zone of Anambra State, Nigeria. The area is drained by Amansea River and its tributaries, has average daily minimum and maximum temperatures of $27^{\circ} \mathrm{C}$ and $34^{\circ} \mathrm{C}$ with mean annual rainfall and relative humidity of $1,600 \mathrm{~mm}$ and $80 \%$ respectively. Indigenes are mainly crop farmers and fishermen but herdsmen have migrated from Northern Nigeria to Amansea both for cattle trade and grazing. Amansea is a conducive environment for tick development and survival.

Sample population and sampling procedure: A total of 200 from523 cattle in pasture at Amansea were randomly selected, thenvisually and manually sampled for ticks, with the consent and assistance of the herdsmen, between August 2012 and January 2013. All ticks detached from fifteen attachment sites described as shown in Plate 1 [12] were preserved in separately labeled jam jars containing $70 \%$ ethanol for subsequent identification. 


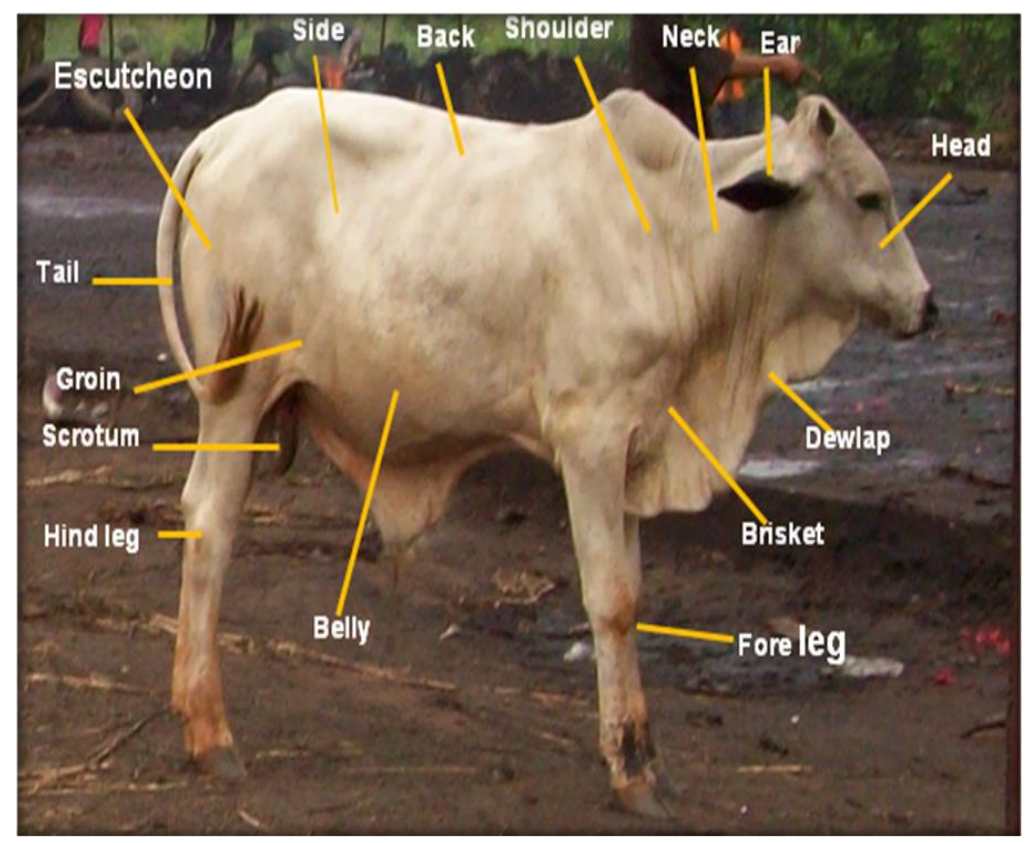

Plate 1: Attachment sites of ticks on cattle [12].

Identification of ticks: Voucher specimens of the preserved ticks were cleared of debris, dried on filter paper, before examination and identification to genera and species levels using the Keys for Identification of African ticks [15].

Data analysis: Data obtained were subjected to descriptive statistics for totals, percentages, mean and standard deviation; variable data were also subjected to Chi square $(\chi 2)$ statistics to determine any differences at 5 and $1 \%$ level of significance [16].

\section{RESULTS AND DISCUSSIONS}

Four cattle types shown in Table 1 were encountered at Amansea, with an average tick infestation rate of 2.87 ticks per infested cattle.

Table 1: Infestation rate of ticks on cattle at Amansea

\begin{tabular}{lllll}
\hline Cattle types & $\begin{array}{l}\text { No. of cattle } \\
\text { examined }\end{array}$ & $\begin{array}{l}\text { No. of cattle } \\
\text { infested }\end{array}$ & $\begin{array}{l}\text { No. of ticks } \\
\text { detached }\end{array}$ & $\begin{array}{l}\text { No. of tick per } \\
\text { infested cattle* }\end{array}$ \\
\hline White Fulani & 65 & 49 & 78 & $1.59^{\mathrm{a}}$ \\
Red Fulani & 15 & 13 & 106 & $8.15^{\mathrm{b}}$ \\
N'Dama & 85 & 36 & 92 & $2.55^{\mathrm{a}}$ \\
Sokoto Gudali & 35 & 28 & 86 & $3.0^{\mathrm{c}}$ \\
\hline
\end{tabular}

* Infestation rate with different superscripts are significantly different at $5 \%$ level $(\mathrm{p}>0.05)$

The observation that N'Dama and White Fulani cattle were more preponderant but recorded less infestation rates than Red Fulani and Sokoto Gudali which were fewer in numbers suggested that ticks at Amansea prefer certain breeds of cattle to others. Previous workers who reported more ticks on White Fulani than on darkly coloured breeds claimed that white colour attracts ticksmore readily than dark colours [17]. The fact that ticks were easily noticed on white bodied animals and detached more frequently by herdsmen may also result in fewer numbers observed on N'Dama and White Fulani cattle in this study but factors such as heat and carbon dioxide 
emitted by cattle as well as attraction-aggregation-attachment pheromones secreted by attached male ticks are known to enhance attachment ofticks on cattle [12]. Acaricidal treatments of cattle by herdsmen in the study area have been reported [18] but the level of acaricidal use on the examined cattle was not revealed by herdsmen interviewed during the study. However, Bos indicus (White Fulani) i.e., Bunaji cattle are thought to be naturally more resistant to infestation with cattle ticks than Bos taurus (Red Fulani, N'dama) though considerable variation in resistance occurs within and between breeds [19]. Plates 2-5 show the salient morphological features observed on representative samples of Amblyomma, Boophilus and Rhipicephalus species encountered on cattle in the study area.

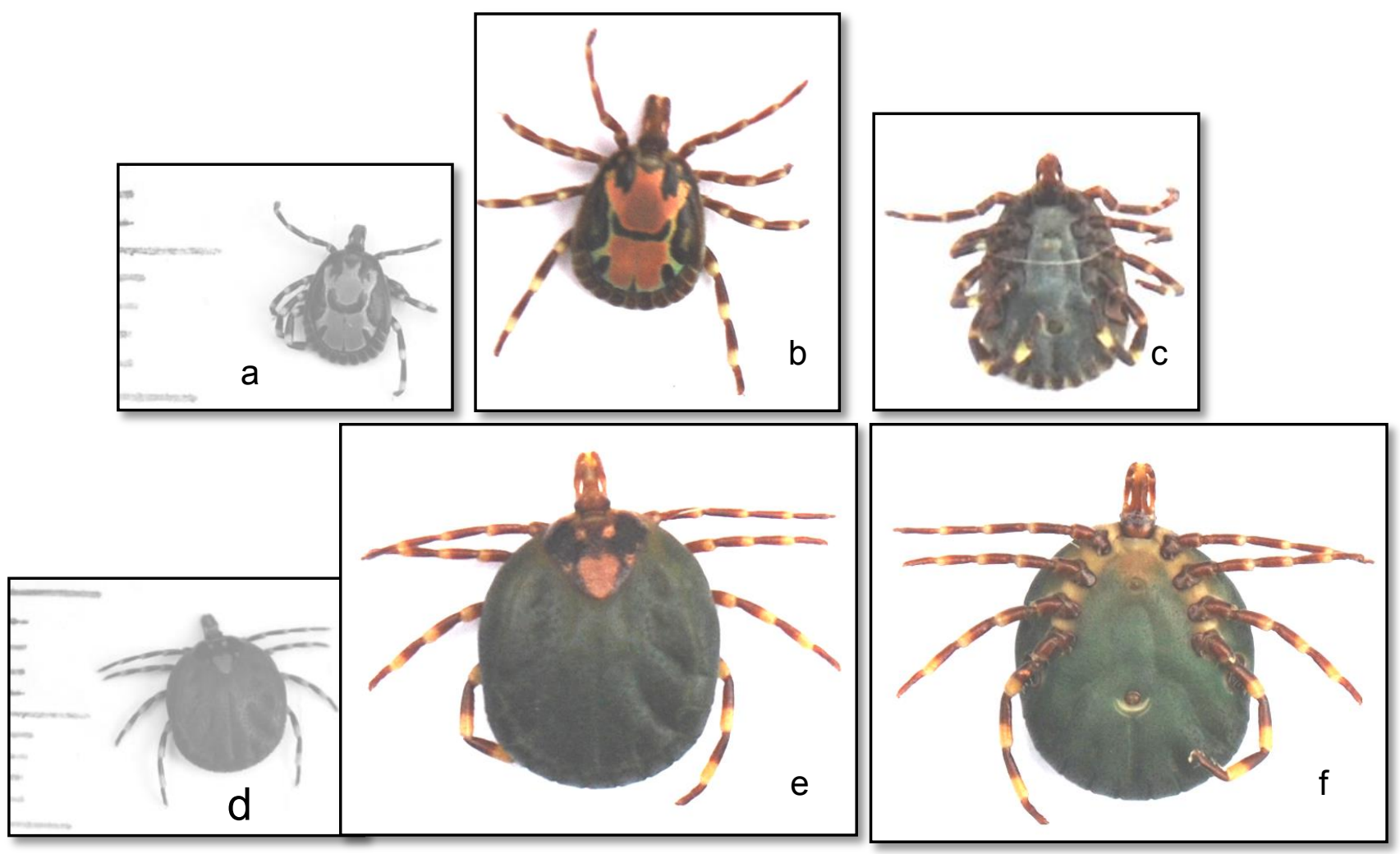

Plate 2: [a] Adult male of Amblyomma variegatum $(5 \times 3 \mathrm{~mm})$; [b, c] dorsal and ventral views of engorged male; [d] Adult female A. coherens $(7 \times 5.5 \mathrm{~mm}),[\mathrm{e}, \mathrm{f}]$ dorsal and ventral views of engorged female. 


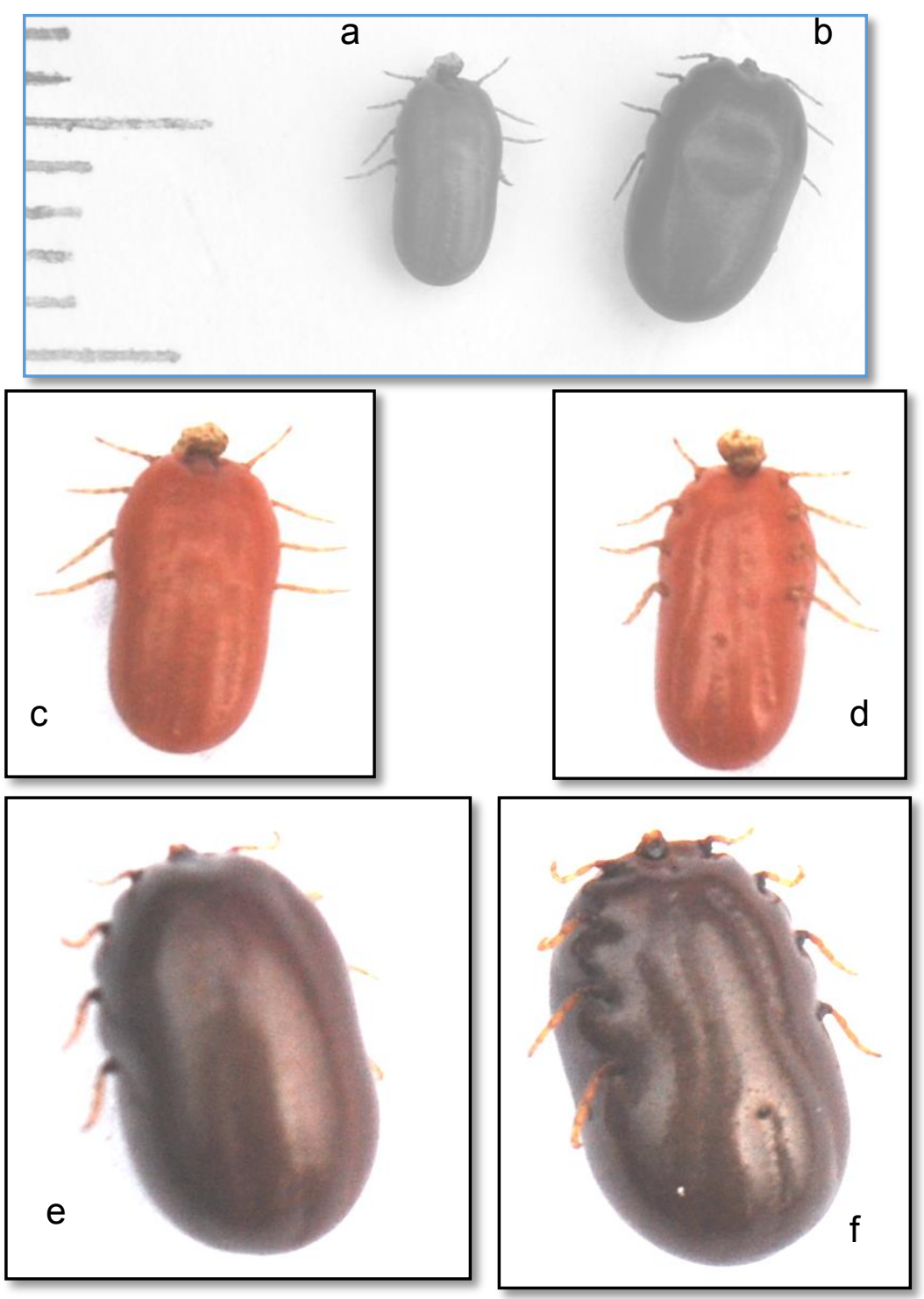

Plate 3: [a] Nymph of Boophilus species $(4.5 \times 2 \mathrm{~mm})$; [b] adult of Boophilus species $(6.5 \mathrm{x} 3.5 \mathrm{~mm})$; [c, d] dorsal \& ventral views of engorged nymph; [e,f] dorsal and ventral views of engorged female.
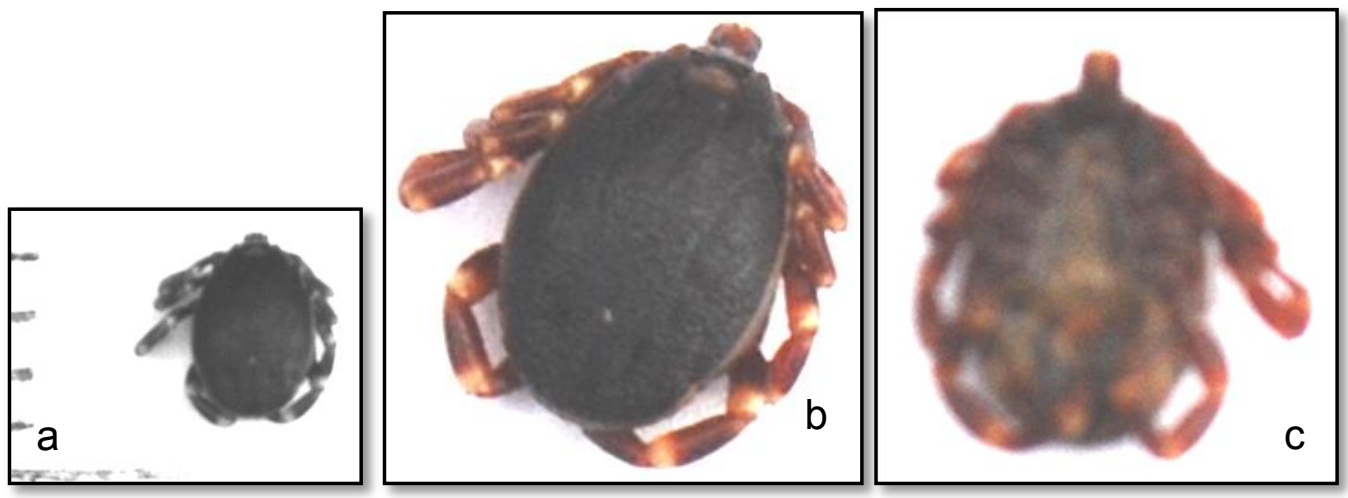

Plate 4: [a] Adult male of Rhipicephalus species (3.0x2.5mm), [b, c] dorsal \& ventral views of engorged male. 


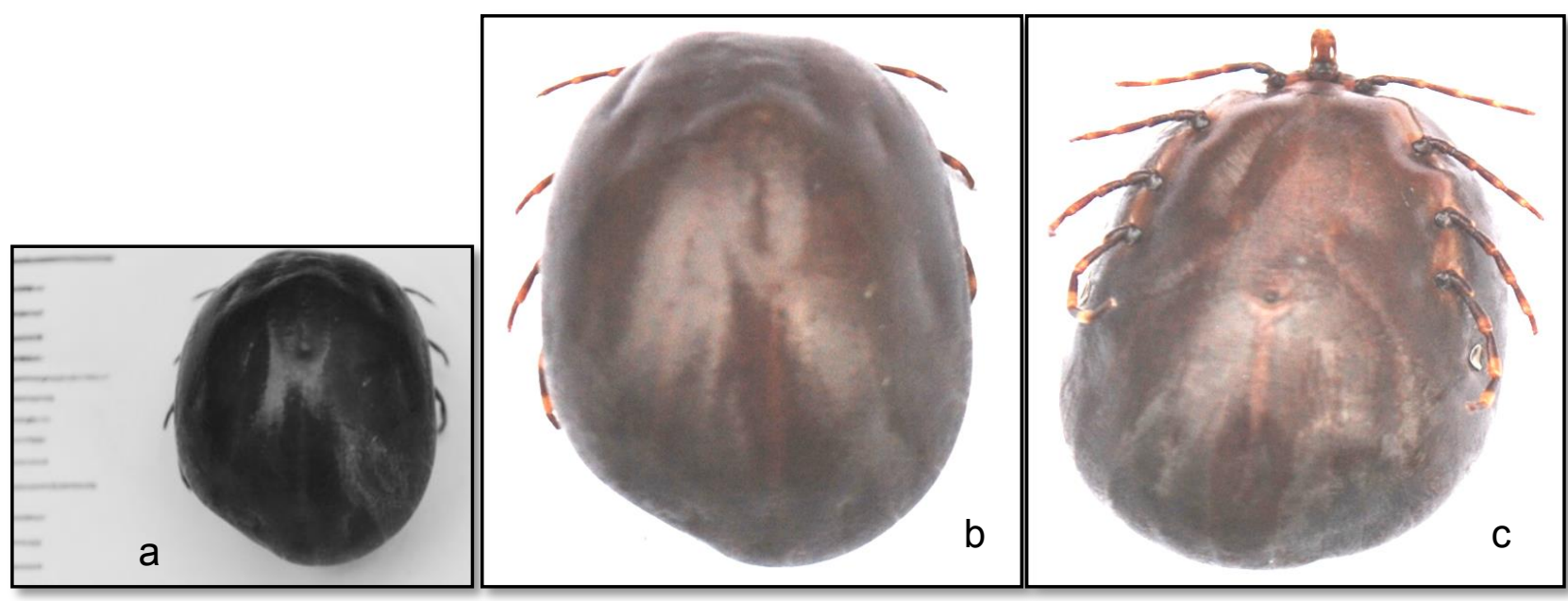

Plate 5: Adult female of Rhipicephalus species (13.0x11.5mm); [a, b] dorsal \& ventral views of engorged female.

Although differences occurred in the distribution of these genera of ticks, infestations with the very abundant Amblyomma species (Figure 1) were not independent of cattle types at both 5\% and $1 \%$ levels of significance $(\chi 2 \mathrm{cal}=7.5640, \chi 2 \mathrm{crit} 0.05=16.919, \chi 2$ crit0.01 $=21.666, \mathrm{df}=9$, $\mathrm{p}>0.01$. The findings that Amblyomma species represented about $60 \%$ of the total ticks collected in this study were in line with similar results on tick species encountered on cattle at two cattle markets in Anambra and Enugu States [13], Zaria abattoir [11] and Iddah Local Government Area of Kogi State Nigeria [20].

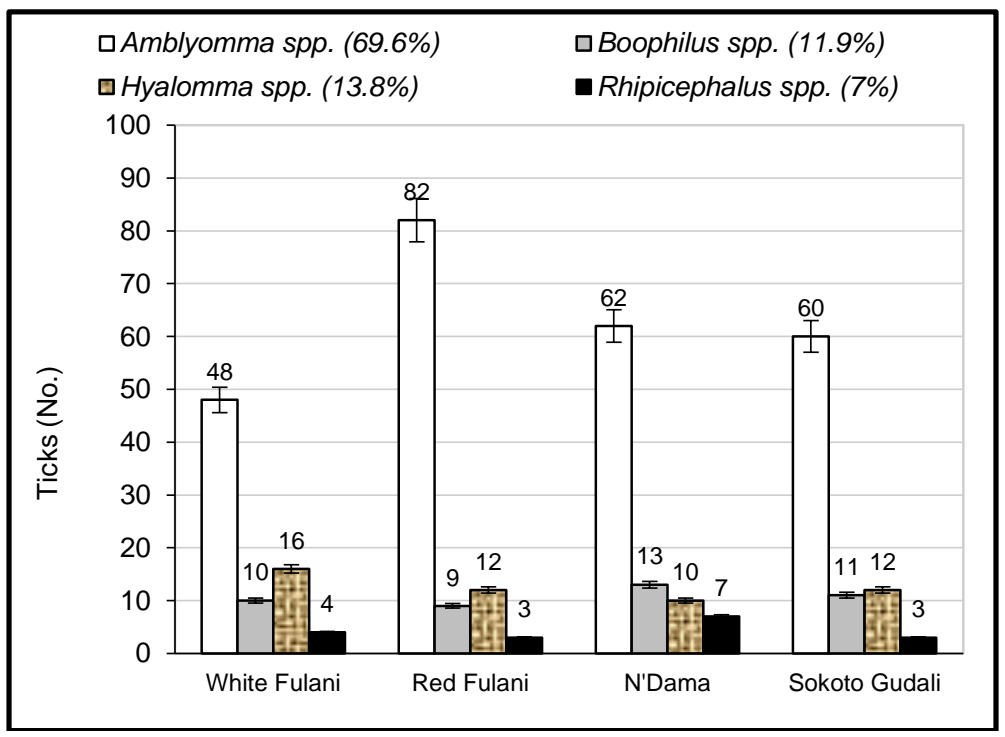

Figure 1: Genera of ticks found on cattle types at Amansea

With the exception of Amblyomma species, there were no marked differences in seasonal distribution of other ticks found on cattle at Amansea. Generally, the ticks recovered during late wet season were numerically more than those of early dry season (Figure 2). This is in line with the findings that higher infestation rates were between months of August and September [21,11]. 


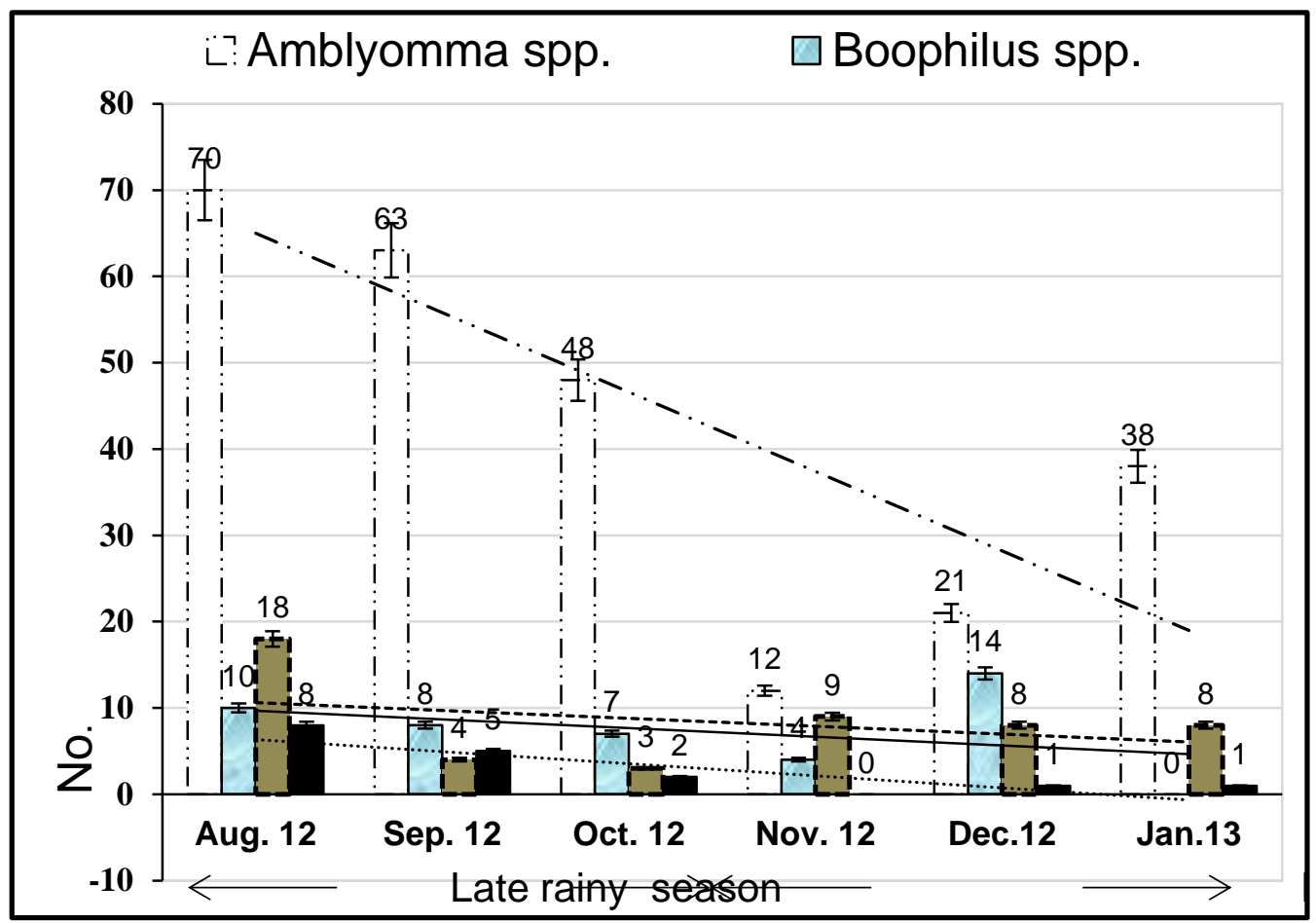

Figure 2: Seasonal occurrence of ticks on cattle at Amansea

The average Sex ratio ( $\left.\delta^{\lambda}: q\right)$ of ticks encountered on cattle at Amansea was 1.9:1 (Table 2). Generally, there were more males than females, perhaps due to the fact that fully engorged female ticks drop off to the ground to lay eggs but the males tend to remain on the host for several weeks or months to mate with as many female as possible on the host before dropping off to die; so that males normally remain on the host longer than females [22](Solomon et al., 2001).

Table 2: Sex ratio of adults of genera of ticks found on cattle

\begin{tabular}{|c|c|c|c|c|}
\hline \multirow[t]{2}{*}{ Cattle type } & Amblyomma spp. & Boophilus spp. & Hyalomma spp. & Rhipicephalus spp. \\
\hline & $\hat{O}: q$ & $\hat{\sigma}:+$ & ô: + & $\hat{O}^{\lambda}: 9$ \\
\hline White Fulani & $2.3: 1$ & $1: 1$ & $1.5: 1$ & $2: 1$ \\
\hline Red Fulani & 1.9: 1 & 1.5: 1 & 1.7: 1 & $1.5: 1$ \\
\hline N'Dama & 1.9: 1 & $2.5: 1$ & 1: 1 & 1.5: 1 \\
\hline Sokoto Gudali & 1.9: 1 & 1.5: 1 & $1: 1$ & $1.5: 1$ \\
\hline
\end{tabular}

Male to female ratio of ticks on cattle found in Nnamdi Azikiwe University (UNIZIK) premises Awka also showed that males were usually more in number than the females [12]. The same trend was reported for ticks on cattle in southeast Ethiopia [23], and in southwestern Ethiopia [24]. The sex ratios of all tick species identified around Assosa Town in Ethiopia were also skewed towards male except for Boophilus decoloratus [25].

Attachment of genera of ticks on cattle was highly dependent on preferred sites on cattle at Amansea (Table 3) but we did not ascertain the extent to which use of acaricides by herdsmen affected the occurrence and distribution of ticks. Generally, Amblyomma species occurred on 
almost all parts of the body but that genera of ticks are dependent on preferred attachment sites on cattle $(\chi 2 \mathrm{cal}=175.8472 ; \chi 2 \mathrm{crit} 0.05=58.124 ; \chi 2 \mathrm{crit} 0.01=66.206), \mathrm{df}=42 ; \mathrm{p}<0.01)$.

Table 3: Attachment of genera of ticks at preferred sites on cattle at Amansea

\begin{tabular}{|c|c|c|c|c|c|c|c|}
\hline \multicolumn{2}{|c|}{ Preferred site } & $\begin{array}{l}\text { Amblyomma } \\
\text { spp. }\end{array}$ & $\begin{array}{l}\text { Boophilus } \\
\text { spp. }\end{array}$ & $\begin{array}{l}\text { Hyalomma } \\
\text { spp. }\end{array}$ & $\begin{array}{l}\text { Rhipicephalus } \\
\text { spp. }\end{array}$ & Total & $\%$ \\
\hline 1. & Scrotum/udder & 38 & 15 & 11 & 1 & 65 & 17.9 \\
\hline 2. & Tail & 21 & 0 & 13 & 3 & 37 & 10.2 \\
\hline 3. & Back & 31 & 3 & 0 & 1 & 35 & 9.7 \\
\hline 4. & Foreleg & 29 & 0 & 1 & 0 & 30 & 8.3 \\
\hline 5. & Neck & 19 & 4 & 5 & 0 & 28 & 7.7 \\
\hline 6. & Ear & 16 & 7 & 0 & 4 & 27 & 7.5 \\
\hline 7. & Dewlap & 18 & 5 & 4 & 0 & 27 & 7.5 \\
\hline 8. & Groin & 23 & 0 & 0 & 1 & 24 & 6.6 \\
\hline 9. & Head & 18 & 2 & 0 & 3 & 23 & 6.3 \\
\hline 10. & Brisket & 15 & 5 & 0 & 0 & 20 & 5.5 \\
\hline & Belly & 17 & 0 & 0 & 2 & 19 & 5.3 \\
\hline & Shoulder & 0 & 0 & 12 & 1 & 13 & 3.6 \\
\hline & Side & 7 & 2 & 0 & 0 & 9 & 2.5 \\
\hline & Hind leg & 0 & 0 & 4 & 0 & 4 & 1.1 \\
\hline 15. & Escutcheon & 0 & 0 & 0 & 1 & 1 & 0.3 \\
\hline To & & 252 & 43 & 50 & 17 & 362 & 100 \\
\hline
\end{tabular}

A similar survey of ectoparasites of cattle in Bukuru near Jos Nigeria revealed that Amblyomma species could occur all over the body, Boophilus species on the neck and scrotal areas, and Hyalomma on the abdomen and limbs [26]. Most ticks recovered from cattle at Enugu Nigeria were from the neck region, hind limb, back, scrotumludder, and forelegs [13]. The presence of ticks in these sites could be probably due to their exposure to the questing ticks as the cattle move about to graze. Also these sites can also act as protective coverings from desiccation by sunlight and hiding places for the ticks. The sites also make ticks less accessible to natural preys and prevent dislodgement of ticks by cattle movements and grooming [13].

Public health importance as well as economic loss in livestock production due to the genera Amblyomma spp., Boophilus spp., Hyalomma spp., and Rhipicephalusspp. in Nigeria have been reported [27]. Amblyomma variegatum causes dermatitis, transmits Cowdria ruminantum (agent of heart water disease in ruminants), virus of $\mathrm{Q}$ fever (Coxiella burneti), and Dermatophilus congolensis responsible for Cutaneous Strepthothricosis that damages hides and skin of Nigeria's cattle [28,29]. A. variegatum also transmits Rickettsia africae, the causative agent of African Tick-bite fever [30]. The role of Boophilus species in human babesiosis has been elucidated $[31,32,4]$ while the incidence and economic significance of equine babesiosis in Lagos and Ibadan in Nigeria were reviewed by [33]. Hyalomma species are primary vectors for Crimean Congo Hemorrhagic Fever (CCHF) virus that is endemic throughout Africa [34], and Hyalomma truncatum have been implicated as vectors of $\mathrm{Q}$ fever, responsible for tick-paralysis in Africa [15]. In Equatorial Africa, all stages of Rhipicephalus appendiculatus feed throughout the year, resulting in inter-stadial transmission of pathogens, especially Theileria parva parva that causes Theileriosis which is a very deadly disease of cattle [35]. 


\section{CONCLUSIONS AND RECOMMENDATIONS}

This study provides new information on cattle types and their tick infestation rates in Amansea, Anambra State. It also documented the sex ratio of all tick genera found on the cattle types, including the seasonality and preferred attachment sites of the ticks on cattle. Potential tick-bites areas which abound in Amansea are risk factors for tick-borne diseases (TBD) known to be transmitted by ticks in West Africa. Results from this study will create public awareness on TBD and will be useful in evidence-based policy decisions on restriction of cattle movement, tick control and surveillance of TBD in the area. Further studies should therefore be carried out to ascertain the status of tick-borne infectious diseases in cattle and humans in the study area and to initiate the process of their control in the study area.

\section{REFERENCES}

[1] Oluwoch, J. M., Revers, B and van Jaarsveld, A. S. (2009). Host parasite distribution pattern under stimulated climate implications for tick-borne diseases. International Journal of Climatology, 29: 993-1000.

[2] Okello, O. J., Tukahiriwa, E. M., Perry, D. B., Rowlands, G. J., Ngada, S. N., Musisi, G., Bode, E., Heinonen, R., Mwayi, W and Opuda, A. J. (2003). The impact of tick control on the productivity of indigenous cattle under ranch conditions in Uganda. Tropical Animal Health and Production, 35(3): 237-247

[3] Rajput, Z., Hu, S., Chen, W and Xiao, C. (2006). Importance of ticks and their chemical and immunological control in livestock. J Zhejang University Science, 7(1): 912-921.

[4] Ikpeze, O. O., Eneanya, C. I and Nwokedi, O. J (2007). Environmental Surveillance of Canine Babesiosis as an Early Alert System on Emerging Human Babesiosis. Journal of Advancement in Medical and Pharmaceutical Science, 1(3): 19-23.

[5] Jongejan, $F$ and Uilenberg, G. (2004). The global importance of ticks. Parasitology, 129: S3-S14.

[6] Viljoen, D.I (1986). Isolation of a neurotoxin from the salivary glands of female Rhipicephalus evertsi evertsi. Journal of Parasitology, 72: 865-874.

[7] Biu, A. A., Nwosu, C. O. (1998). Seasonal prevalence of cattle ticks in Maiduguri, BornoState. Entomology in the Nigerian Economy Research Focus in 21st century. 133139.

[8] Pukuma, S. M., James-Rugu, N. N and Sale, M. (2011). A study on tick borne infectionsof cattle in Yola locality Adamawa State. African Journal of Agricultural Research, 6: 6208-6211.

[9] Marufu, M. C., Qokweni, L., Chimonye, M., Dzama, K. (2011). Relationship between tick counts and coat characteristics in Nguni and Bonsmara cattle reared on semi aridrange lands in South Africa. Ticks and Tick-borne Diseases. Elseveir, 2: 172-177.

[10] Ayana D, Eshetu D and Abunna F, 2013. Survey of Ixodid ticks on cattle in Borana pastoral area, Ethiopia. Acta Parasitologica Globalis, 4(1): 14-23.

[11] Obadiah, H. I and Shekaro, A. (2012). Survey of tick infestation in cattle in Zaria Abattoir, Nigeria. Journal of Veterinary Advances, 2(2): 81-87.

[12] Ikpeze, O. O. (2012). Ecology of ticks (Acarina: Ixodidae) on cattle in Nnamdi AzikiweUniversity Awka, Anambra State, Nigeria. PhD. Thesis. Department of Parasitology and Entomology, Nnamdi Azikiwe University, Awka. pp.114. 
[13] Ikpeze, O. O., Eneanya, C. I., Chinweoke, O. J., Aribodor, D. N and Anyasodor, A. E. (2011). Species diversity, distribution and predilection sites of ticks (Acarina: Ixodidae ontrade cattle at Enugu and Anambra States, South-eastern, Nigeria. The Zoologist, 9: $1-8$.

[14] Ikpeze., O. O. (2010). Distribution of parasitic ticks (Acarina: Ixodidae) on cattle at designated cattle markets in Enugu, Ugwuoba nd Amansea, south-eastern Nigeria. International Journal of Biological Science, 2(3): 51-55.

[15] Okello-Onen, J., Hassan, S. M and Essuman, S. (1999). Taxonomy of African Ticks: AnIdentification Manual. ICIPE Science Press, Nairobi.

[16] Roa, K.V (2007). Biostatistics. A manual of statistical methods for use in Health, Nutrition and Anthropology. Jaypee Brothers Medical Publishers (P) LTD New Delhi. pp.725.

[17] Opara, M.N and Ezeh, N.O. (2011). Ixodid ticks of cattle in Borno and Yola states of Northeastern Nigeria: breed and coat colour preference. Animal Research International, 8(1): 1359-1365.

[18] Ikpeze, O. O and Mbanugo, J. I. (2005). Bioassays and Susceptibility of Adult Ticks (Acarina: Ixodidae) to Diazinon Dimpylate. Bio-Research, 3(2): 37-39. ISSN: 15967409.

[19] Piper, E. K., Jonsson, N. N., Gondro, C., Ala, E. L, Moolhuijzen, P., Vance, M .E and Jackson L. A. (2009). Immunological profiles of Bos Taurus and Bos indicus cattle infested with the cattle tick Rhipicephalus microplus. Clinical and Vaccine Immunology, 16: 1074-1086.

[20] Ejima, I. A and Ayegba A. E. (2011). Relative abundance of hard ticks on reared cattle(Family Bovidae: Bos spp.) in Idah Local Government Area, Kogi State, Nigeria. The Zoologist, 9: 9-16.

[21] Arong, G. A., Shutta, K. B., James-Rugu, N. N and Effanga, E. O. (2011). Seasonal variation in the abundance and distribution of Ixodid ticks on mongrel, alastian and mixed breeds of dogs (Canis familiaris) in Jos. World Journal of Science and Technology, 1(4): 24-29.

[22] Solomon, G., Nigist, M and Kassa, B. (2001). Seasonal variation of ticks on calves at Sebeta in western Shewa Zone. Ethiopia Veterinary Journal (1 and 2): 17-30.

[23] Tessema, T and Gashaw, A. (2010). Prevalence of ticks on local and cross bred cattle inand around Asella Town, southeast Ethiopia. Ethiopia Veterinary Journal, 14(2): 7989.

[24] Tadesse, F., Abdfaji, G., Girma, S., Kumsa, B and Jibat, T. (2012). Identification of tick species and their preferred site on cattle body in and around Mizan Tefori, Southwestern Ethiopia. Journal of Veterinary Medicine and Animal Health, 4(1):1-5.

[25] Bossena Fantahun and Abdu Mohamed (2012). Survey on the distribution of tick species in and around Assosa town, Ethiopia. Journal of Veterinary Sciences, 5: 32-41.

[26] Olabode, H.O.K., Silas, P.M and Agbede, R.I.S (2010). Survey of ectoparasites and their predilection sites on cattle in Bukuru Market. Journal of Agricultural and Veterinary Science, 2: 20-74.

[27] Fasanmi, F and Onyima, V. C (1992). Current concepts in the control of ticks and tickborne diseases in Nigeria - A review. International Journal of Tropical Insect Science, 13: 625-619. 
[28] Ikpeze, O. O. (2004). Dermatophilus Infection in Nigeria: A Mini-Review. BioResearch, 2(2): 37-41. ISSN: 1596-7409.

[29] Okoye, J.O.A and Ikeme, M.M (1990). Acute dermatitis caused by Amblyomma variegatum larvae in chickens. Avian Pathology, 19(4): 785-789.

[30] Mediannikov, O., Trape, J., Diatta, G., Parola, P., Fournier, P and Raoult, D (2010). Rickettsia africae, Western Africa. Emerging Infectious Diseases, 16(3): 571-573.

[31] Haapasalo, K., Suomalainen, P., Sukura, A., Siikamaki, H and Jokiranta, T.S (2010). Fatal Babesiosis in man, Finland. Emerging Infectious Diseases, 16(7): 1116-1118.

[32] Karakashian, S.J., Rudzinska, M.A., Spielman, A., Lewengrub, S., Piesman, J and Shoukrey, $N$ (1983). Ultra structural studies on sporogony of Babesia microti in salivary gland cells of tick Ixodes dammini. Cell Tissue Research, 231: 275-278. DOI:10.10007/BF00222180.

[33] Oladosu, L.A and Dipeolu, O.O (1983). The incidence and economic significance of equine babesiosis in Lagos and Ibadan, Nigeria. Proceedings of the National Symposiumon Control of ticks and tick-borne diseases in Nigeria.

[34] Knust, B., Medetov, Z.B., Kyraubayev, K.B., Bumburidi, Y., Erickson, B.R., MacNeil, A., Nichol, S.T., Bayserkin, B.S and Ospanov, K.S (2012). Crimean-Congo Hemorrhagic Fever, Kazakhstan, 2009-2010. Emerging Infectious Diseases, 18(4): 643-645. 